dr. Angelca

Ivančič

Andragoški center

Slovenije

\section{TRŽNO GOSPODARSTVO IN IZOBRAŽEVANJE ZAPOSLENIH} Vlaganje $v$ izobraževanje zaposlenih na
prehodu $v$ tržno gospodarstvo

$\mathrm{S}_{\mathrm{r}}$ plošno prepričanje je, da so strukturne spremembe na trgu dela, ki jih je povzročil prehod iz socialističnega $\mathrm{v}$ tržno gospodarstvo, pomembno vplivale tudi na strukturo potreb po kvalifikacijah. Pri tem mislimo na povečevanje izobrazbenih in kvalifikacijskih zahtev in na spremembe $\mathrm{v}$ vsebinski strukturi kvalifikacij. Ta pričakovanja so podprta $\mathrm{z}$ dejavniki, kot so:

a) krčenje delovnih mest $v$ tradicionalnih industrijskih in storitvenih dejavnostih, ki so temeljile na slabše kvalificirani delovni sili;

b) nastajanje malih podjetij in firm, ki potrebujejo široko usposobljene ljudi, ki lahko prevzemajo različne naloge in opravila;

c) nastajanje novih dejavnosti in poklicev $\mathrm{v}$ storitvenem sektorju;

č) deregulacija trga dela, ki omogoča nadomeščanje tradicionalnih stalnih zaposlitev $\mathrm{s}$ fleksibilnejšimi manj stabilnimi oblikami.

Iz javnih sredstev se financira pretežno izobraževanje in usposabljanje ogroženih skupin (brezposelni, invalidi, presežni delavci), delodajalci vlagajo $\mathrm{v}$ izobraževanje zaposlenih na ključnih delovnih mestih (t. i. jedro zaposlenih), zaposlenim, ki niso $\mathrm{v}$ nobeni od teh skupin, pa je dostop do organiziranih izobraževalnih aktivnosti v dokajšnji meri otežen.

Prilagajanje tem spremembam zahteva intenzivno vlaganje $\mathrm{v}$ stalno pridobivanje novih in prilagajanje ter dopolnjevanje obstoječih kvalifikacij. Ukrepi delodajalcev za povečevanje konkurenčnosti so lahko uspešni le ob ustrezno usposobljeni delovni sili, pri zaposlenih pa se vlaganje $\mathrm{v}$ izboljševanje kvalifikacij spreminja v ukrep, nujen za ohranjanje zaposlitve.

Izobraževanje in usposabljanje zaposlenih naj ne bi pomenilo samo prilagajanja njihovih kvalifikacij zahtevam delovnih mest in pokli- cev, temveč bi moralo biti čedalje bolj naravnano $k$ vzdrževanju njihove zaposljivosti. Vendar je ekonomska kriza, ki je dosegla kulminacijo na prehodu v tržno gospodarstvo, občutno zmanjšala pripravljenost delodajalcev za vlaganje v razvoj človeških potencialov. Med prvimi racionalizacijskimi ukrepi, ki so jih uvedle delovne organizacije, je bilo prav ukinjanje podjetniških izobraževalnih centrov in služb ter zmanjševanje osebja, pristojnega za organizacijo izobraževanja in usposabljanja. Upoštevaje procese, ki spremljajo prestrukturiranje podjetij, lahko sklepamo, da dajejo delodajalci pri prilagajanju izobrazbene in kvalifikacijske strukture prednost generacijski menjavi pred vlaganjem v izboljševanje obstoječih kvalifikacij. Hkrati se je zmanjšala tudi individualna zmožnost vlaganja v izobraževanje, v nasprotju z nekaterimi drugimi evropskimi državami (Avstrija, skandinavske države, Francija) pa ni razvitih mehanizmov, ki bi spodbujali individualno povpraševanja po izobraževanju zaposlenih, $\mathrm{v}$ katere delodajalci niso pripravljeni vlagati, sami pa za to nimajo možnosti ali pa niso ustrezno motivirani.

Vendar je v zadnjem obdobju prišlo do sorazmerne umiritve gospodarskih razmer, zato se zdi upravičeno pričakovati, da se oboji, delodajalci in zaposleni od kriznih postopoma preusmerjajo $k$ adaptacijskim vzorcem ravnanja, med te pa uvrščamo tudi sprejemanje filozofije potrebnosti stalnega vlaganja $\mathrm{v}$ izobrazbo in kvalifikacije.

\section{VKLJUČEVANJE ZAPOSLENIH V ORGANIZIRANO IZOBRAŽEVANJE IN USPOSABLJANJE}

Omenjeno je bilo, da imajo na splošno različne kategorije zaposlenih različne možnosti 
dostopa do organiziranih izobraževalnih aktivnosti. Splošno znano je, da se izobražujejo predvsem ljudje, ki imajo doseženo višjo raven formalne izobrazbe, mlajše starostne skupine in ljudje, ki so na trgu delovne sile (prim. Davis 1996). Tudi razpoložljivi podatki za Slovenijo (Ivančič 1996; Smonkar 1994) so skladni z ugotovitvami o pomenu dosežene formalne izobrazbe, starosti in ekonomske aktivnosti pri odločanju za vključevanje $\mathrm{v}$ izobraževanje in usposabljanje po končanem mladinskem izobraževanju. Pri zaposlenih poleg izobrazbe in starosti na odločanje za izobraževanje pomembno vplivajo:

- položaj pri delu (zahtevnost delovnega mesta),

- velikost organizacije in

- gospodarska dejavnost.

Struktura povpraševanja po izobraževanju pomembno oblikuje izobraževalno ponudbo, zato ne preseneča, da je ta pretežno usmerjena $\mathrm{k}$ tistim skupinam, ki so tradicionalno njeni najpomembnejši porabniki. To še dodatno zožuje možnosti izobraževanja najbolj odrinjenih skupin zaposlenih.

$\mathrm{V}$ nadaljevanju so predstavljeni podatki o vključenosti zaposlenih $\mathrm{v}$ organizirano izobraževanje in usposabljanje v letu 1995. Omejujemo se na: izobraževanje za pridobitev izobrazbe, prekvalifikacije, usposabljanje za delo po programih (USO), specializacije, izobraževanje in usposabljanje, ki ga terjajo zakonski predpisi, ter krajše oblike strokovnega izobraževanja, usposabljanja in izpopolnjevanja. Podatki so bili zbrani z letno statistično raziskavo ŠOL-ZAP'. Raziskava zajema podjetja in firme $\mathrm{z}$ več kakor 10 zaposlenimi. Ob tem je treba opozoriti, da je organizirano izobraževanje zaposlenih samo del izobraževanja; pričakujemo, da postaja vse pomembnejši tisti del izobraževanja in učenja, ki poteka po poteh, ki jih navadno statistično ne spremljamo (samoizobraževanje, priložnostno učenje).

Grafa prikazujeta deleže zaposlenih, vključenih $\mathrm{v}$ vse opazovane vrste izobraževanja v letih 1989, 1993 in 1995, torej v obdobju intenzivnih strukturnih sprememb $\mathrm{v}$ slovenskem gospodarstvu. V letu 1993 ni zaslediti večjih sprememb v primerjavi $\mathrm{z}$ letom 1989 , leta 1995 pa se je v primerjavi z letom 1989 delež udeležencev že povečal na $58,4 \%$ zapo-
Graf 1: Zaposleni v izobraževanju v letih 1989, 1993 in 1995

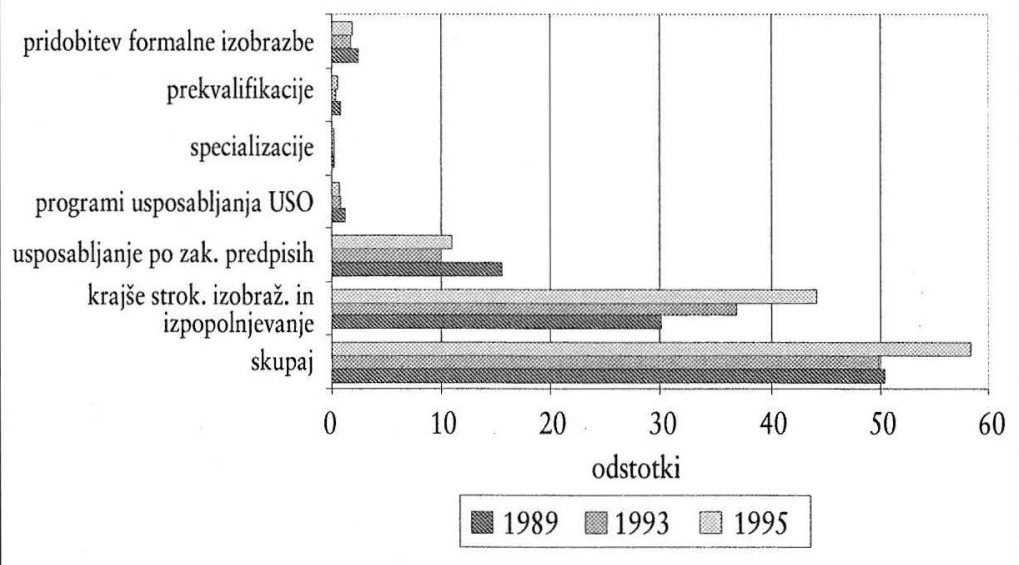

Graf 2: Zaposleni v gospodarstvu in izobraževanju 1989, 1993 in 1995

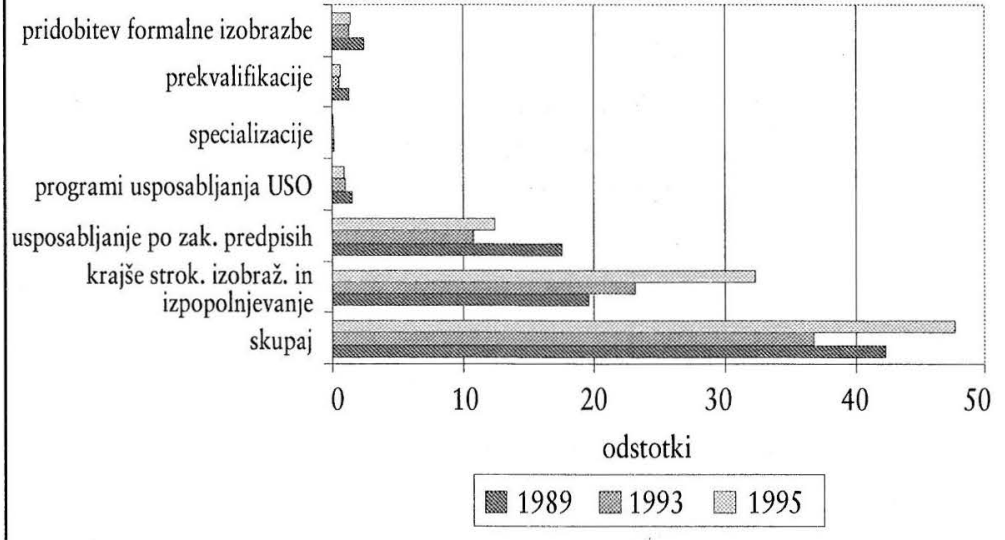

slenih. To kaže, da so strukturne spremembe vendarle spodbudile $\mathrm{k}$ večjemu vlaganju $\mathrm{v}$ izobraževanje zaposlenih. Ob tem se takoj postavi vprašanje, ali ta na videz ugoden podatek dejansko nakazuje bistveni premik na tem področju. Že dejstvo, da je delež udeležencev iz gospodarskih dejavnosti precej manjši od povprečnega deleža (graf 2), opozarja, da se izobražuje večji delež zaposlenih v storitvah, ki se financirajo iz javnih sredstev, kakor v tržnem sektorju.

Sestava udeležencev po vrstah izobraževanja kaže, da so se leta 1995 v primerjavi z letom 1993 nekoliko povečali deleži zaposlenih, ki so obiskovali programe za pridobitev formalne izobrazbe, programe prekvalifikacij ter izobraževanje in usposabljanje, ki ga zahtevajo zakonski predpisi, kljub temu v nobenem primeru niso dosegli deležev iz leta 1989 (graf 1). Drugačna podoba se kaže pri krajših pro- 
gramih strokovnega usposabljanja in izpopolnjevanja: udeležba $\mathrm{v}$ teh programih se je leta 1995 precej povečala že $\mathrm{v}$ primerjavi $\mathrm{z}$ letom 1993, še bolj pa $\mathrm{v}$ primerjavi z letom 1989 (graf 1); leta 1989 se je teh oblik udeležilo $30,6 \%$ zaposlenih, leta 1993 slabih $37 \%$ in leta 1995 že 44,2\%. Občutno se je povečal

Povečuje se povpraševanje po krajši izobraževalnih programih. tudi delež udeležencev iz gospodarskih dejavnostih, in sicer z 19,6\% leta 1989 na $32,3 \%$ leta 1995 (graf 2).

Kaj nam povedo ti podatki? Kot kaže, se je povečalo predvsem povpraševanje po izobraževanju, usposabljanju in izpopolnjevanju, ki je krajšega trajanja, medtem ko se je nekoliko zmanjšal delež udeležencev v nekaterih daljših programih, predvsem programih za pridobitev izobrazbe. To ne preseneča, saj zaposleni potrebujejo novo znanje in spretnosti takoj in ne šele čez nekaj let, ko končno pridobijo spričevalo ali diplomo. Nadalje imajo končni porabniki izobraževanja pri krajših programih možnost vplivanja na izobraževalno vsebino skladno s svojimi potrebami, cilji formalnega izobraževanja in vsebine, ki vodijo $\mathrm{k}$ tem ciljem, pa so praviloma določeni od zunaj in jih je mnogo težje prilagajati kratkoročnim potre-

Graf 3: Zaposleni v izobraževanju 1995

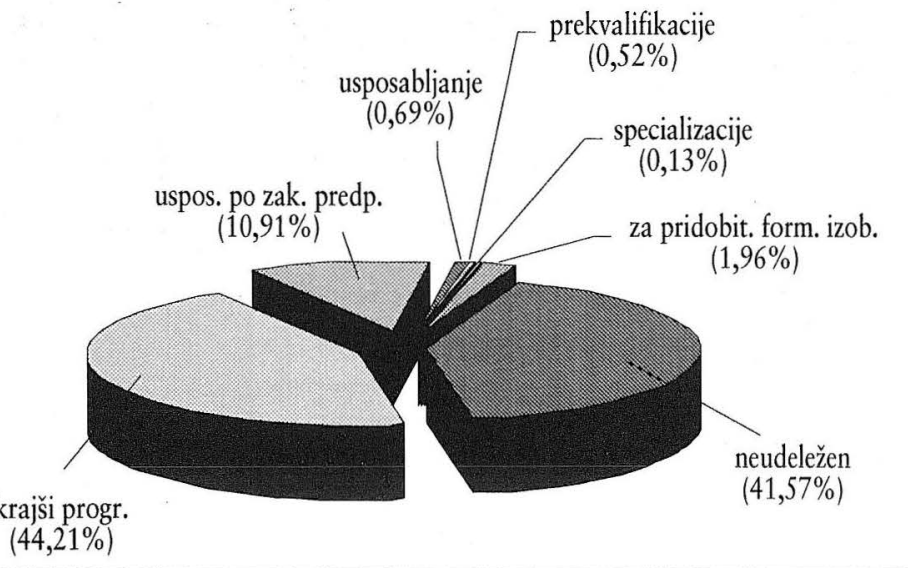

bam delodajalcev in zaposlenih. Krajše izobraževanje je tudi lažje uskladiti $\mathrm{z}$ delovnimi in družinskimi obveznostmi, poleg tega je cenejše za oba, delodajalca in zaposlenega. Ne nazadnje kaže omeniti, da formalna izobrazba povečujejo priložnosti zaposlenih na zunanjem trgu dela, to pa omogoča, da ima lahko koristi od izobraževanja tudi nekdo drug in ne le delodajalec, ki je vanj vlagal.

\section{KAKO SO SE ZAPOSLENI IZOBRAŽEVALI V LETU 1995}

Že bežen pogled na graf 3 pove, da je bilo tudi leta 1995 največ udeležencev krajših oblik strokovnega izobraževanja, izpopolnjevanja in usposabljanja. To velja za vse dejavnosti. $\mathrm{Na}$ drugem mestu je usposabljanje, ki temelji na zakonskih predpisih (od 10 do $18 \%$ zaposlenih); kot bomo videli kasneje, ga v večjem obsegu srečujemo predvsem $\mathrm{v}$ tradicionalnih industrijskih in storitvenih dejavnostih. Daljši, bolj formalizirani programi izobraževanja in usposabljanja so zastopani v relativno zelo majhnem obsegu. V nadaljevanju je prikazana podrobnejša porazdelitev udeležencev posameznih vrst programov izobraževanja in usposabljanja po dejavnostih.

\subsection{Programi za pridobitev formalne izobrazbe}

Prikazi v grafih 1 in 2 opozarjajo, da se je že tako majhen delež udeležencev programov za pridobitev izobrazbe po letu 1989 še zmanjšal; leta 1995 se je sicer nekoliko zvečal, vendar je ostal pod ravnijo iz leta 1989.

Porazdelitev udeležencev po dejavnostih, prikazana $\mathrm{v}$ tabeli $1 \mathrm{a}$, govori o izraziti polarizaciji pri vključevanju v programe za pridobitev izobrazbe: vanje se vključujejo predvsem zaposleni v storitvenem sektorju. Prevladujejo zaposleni $v$ javnih storitvah in državni upravi, $\mathrm{v}$ tržno usmerjenem sektorju pa $\mathrm{v}$ finančnih, tehničnih in poslovnih storitvah. Takšna porazdelitev je nedvomno povezana $\mathrm{z}$ dejstvom, da se formalna izobrazba $v$ navedenih dejavnostih tesno povezuje s profesionalnostjo in torej s kakovostjo storitev, predstavlja pa tudi pomemben dejavnik poklicnega napredovanja. Ker gre praviloma za dejavnosti, ki se financirajo iz javnih sredstev, in za državne birokratske sisteme, je tudi dostop do izobraževalnih možnosti mnogo lažji kakor v dejavnostih, ki so podvržene konkurenci na trgu blaga in storitev. Tako podatek iz leta 1995 govori, da je bilo $44 \%$ vseh udeležencev zaposlenih v družbenih dejavnostih in državni upravi. Udeleženci iz industrije in rudarstva so prispevali $26,6 \%$, iz trgovine $10,15 \%$, iz finančnih, tehničnih in poslovnih storitev $8,45 \%$, na druge dejavnosti skupaj pa je odpadlo $10,8 \%$ vseh udeležencev (tabela 1a). Tudi po deležih zaposlenih sta na vrhu lestvi- 


\begin{tabular}{|c|c|c|c|c|c|c|c|c|}
\hline \multirow[t]{2}{*}{ Dejornosti } & \multirow{2}{*}{ 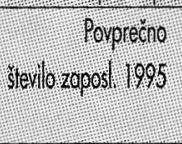 } & \multicolumn{6}{|c|}{ 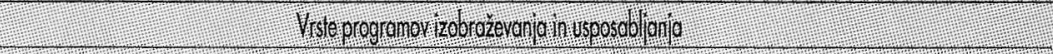 } & \multirow[b]{2}{*}{ Skepoil } \\
\hline & & $\begin{array}{l}\text { zopredobitey } \\
\text { fom izobre }\end{array}$ & specializace. & preksodik. & $\begin{array}{r}\text { usposablianip } \\
\text { USO }\end{array}$ & $\begin{array}{l}\text { uspos. po } \\
\text { zelon preep. }\end{array}$ & $\begin{array}{l}\text { Krajspiproge } \\
\text { izpopedili. }\end{array}$ & \\
\hline industrio in viderstio & 243268 & 3102 & 149 & 1888 & 2448 & 34533 & 7852 & 120662 \\
\hline Gimelitstro in : Gisisvo & 8830 & 234 & 12 & 83 & 108 & 1600 & 3149 & 586 \\
\hline Gozarsio & 2297 & 26 & 1 & 0 & 3 & 252 & 382 & 664 \\
\hline Vodio gospodarstivo & 1070 & 1 & 0 & 0 & 0 & 11 & 104 & 27 \\
\hline Grecbenisto & 29847 & 262 & 6 & 76 & 337 & 490 & 47 & 1068 \\
\hline Promet in zieze & 29918 & 589 & 5 & 37 & 137 & 2877 & 8868 & 1268 \\
\hline Igoving & 55892 & 1804 & 18 & 37 & 168 & 63.13 & 1278 & 2042 \\
\hline Gosfistovintuizen & 15155 & 49 & 2 & 11 & 24 & OPB & 3088 & 427 \\
\hline Obrinosebne storive & 14860 & 78 & 0 & 34 & 140 & 593 & 220 & 1065 \\
\hline Stonovaristo in lonunglno del. & 10822 & 4 & 7 & 20 & 269 & [15] & 3584 & 564 \\
\hline 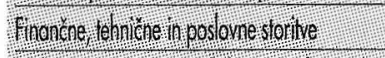 & 36450 & 986 & 26 & 65 & 167 & 1876 & 2880 & 2600 \\
\hline 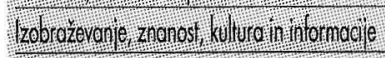 & 51335 & 1585 & 115 & 95 & 7 & 241 & 6418 & 6771 \\
\hline 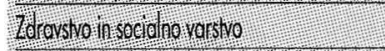 & 54481 & 1685 & 393 & 280 & 172 & 499 & 3509 & 1211 \\
\hline Drevnauprovo & 38092 & 1862 & 58 & 4 & 66 & 2014 & 23389 & 2428 \\
\hline Skupol & $59: 394$ & 11657 & 792 & 30 & 416 & 64865 & 26285 & 34725 \\
\hline \multicolumn{9}{|l|}{ Y odstovith } \\
\hline \multirow{2}{*}{\multicolumn{2}{|c|}{ Dejaveosi }} & \multicolumn{6}{|c|}{ 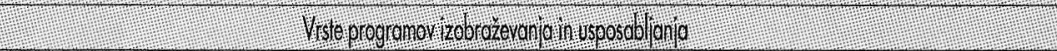 } & \multirow[b]{2}{*}{ Skejpal } \\
\hline & & $\begin{array}{l}\text { zopridobiter } \\
\text { tom. izoor }\end{array}$ & spectelizoc. & prearchliti. & $\begin{array}{r}\text { usposobjipaje } \\
\text { USO }\end{array}$ & $\begin{array}{l}\text { uspos, po } \\
\text { zakor, prede }\end{array}$ & 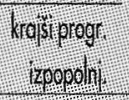 & \\
\hline \multicolumn{2}{|l|}{ nedustipio in vidarstivo } & 1,28 & 0.06 & 078 & 10 & 420 & 30 & 4960 \\
\hline \multicolumn{2}{|l|}{ Kmetisvoinibízvo } & 265 & 0,4 & 01 & 122 & 1812 & 3506 & 5873 \\
\hline \multicolumn{2}{|l|}{ Gozdersivo } & 13 & 0,04 & 0.00 & Q13 & 10.9 & 16.6 & 2891 \\
\hline \multicolumn{2}{|l|}{ Volnogosspodarsvo } & 009 & 000 & 00 & Q00 & 10.47 & 67 & 2028 \\
\hline \multicolumn{2}{|l|}{ Grodbenísvo } & 0,88 & 0,02 & 0,25 & 1,13 & 16.45 & 153 & 3407 \\
\hline \multicolumn{2}{|l|}{ Pomet: in zreze } & 1,9 & 0,02 & 0.46 & 0,46 & 962 & 20.64 & 4216 \\
\hline \multicolumn{2}{|l|}{ Ggovitio: } & $2 n$ & 0,03 & $0: 66$ & 0,30 & 1129 & 24 & $36: 5$ \\
\hline \multicolumn{2}{|l|}{ Gosinstro: in turízen } & 02 & 001 & 0.07 & 016 & 708 & 2638 & $28: 2$ \\
\hline \multicolumn{2}{|l|}{ Obilin escenese slorive } & 052 & 0,00 & 0,23 & 0,9 & 300 & 118 & 717 \\
\hline \multicolumn{2}{|l|}{ 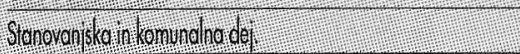 } & 004 & 0,0 & 07 & 2,49 & 162 & 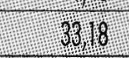 & 525 \\
\hline \multicolumn{2}{|l|}{ 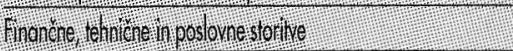 } & 27 & 0,0 & 0 & 0,46 & 515 & 627 & 7133 \\
\hline \multicolumn{2}{|l|}{ laobrozieverie, znonost, kulturo in intormocie } & 3il & 0,2 & 019 & 0,5 & 4,81 & 12,95 & 131,43 \\
\hline \multicolumn{2}{|l|}{ Zerrousvo in sociding varsivo } & 309 & 0,2 & 0,51 & 0,32 & 824 & 64,4 & $\sqrt{20}$ \\
\hline \multicolumn{2}{|l|}{ Dizone uprove } & 478 & 0,15 & प11 & 0,7 & 56 & 65il & 15 \\
\hline \multicolumn{2}{|c|}{ Skupgi } & 196 & 0 & 0,02 & 0.69 & 109 & 4/ & 58.43 \\
\hline \multicolumn{9}{|c|}{ 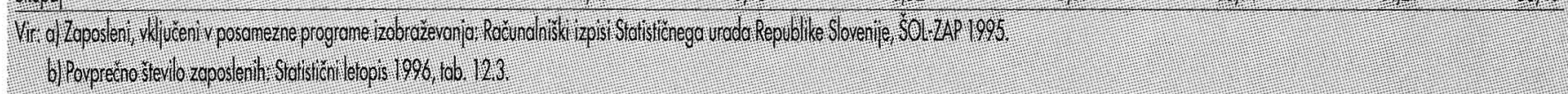 } \\
\hline
\end{tabular}

ce državna uprava in družbene dejavnosti, pridružujeta pa se jim finančne, tehnične in poslovne storitve ter kmetijstvo. Najmanjši deleži zaposlenih, vključenih $\mathrm{v}$ te programe, so bili v stanovanjski in komunalni dejavnosti $(0,04 \%), v$ gostinstvu in turizmu $(0,32 \%)$ ter $\mathrm{v}$ obrti in osebnih storitvah $(0,52 \%)$, torej $\mathrm{v}$ dejavnostih, ki bodisi zaposlujejo slabše kvalificirano delovno silo, so sezonske narave, temeljijo na fleksibilnejših oblikah zaposlova- nja, ali pa $\mathrm{v}$ njih prevladujejo firme $\mathrm{z}$ majhnim številom zaposlenih.

Dejavnosti se med seboj pomembno ločijo tudi po tem, na katerih ravneh formalnega izobraževanja se izobražujejo zaposleni. Če se vrnemo $\mathrm{k}$ tabeli $1 \mathrm{a}$, lahko ugotovimo, da je bilo nekoliko večje povpraševanje po programih nižjega poklicnega izobraževanja le pri zaposlenih $\mathrm{v}$ gradbeništvu ter $\mathrm{v}$ zdravstvu in socialnem varstvu ${ }^{2}$, po programih triletnega 
poklicnega izobraževanja $\mathrm{v}$ trgovini in kmetijstvu, programi štiri- in petletnega srednješolskega ter višješolskega izobraževanja so prevladovali pri zaposlenih $\mathrm{v}$ drugih industrijskih in storitvenih dejavnostih, programi visokošolskega ter podiplomskega izobraževanja pa pri zaposlenih $\mathrm{v}$ zdravstvu in socialnem varstvu, v izobraževanju, znanosti, kulturi in informacijah, $v$ javni upravi ter $v$ finančnih, tehničnih in poslovnih storitvah. Več kot očitno je, da je nižje poklicno izobraževanje aktualno predvsem za zaposlene $\mathrm{v}$ dejavnostih, ki zaposlujejo slabše kvalificirano delovno silo, medtem ko se praviloma udeleženci programov izobraževanja za pridobitev izobrazbe iz drugih dejavnosti odločajo za pridobitev štiri- in petletne srednješolske, višješolske, visokošolske in podiplomske izobrazbe.

\subsection{Programi specializacij}

Po številu udeležencev bi programe specializacij težko označili kot pomembno obliko izobraževanja zaposlenih (graf 1). Vanje se vključuje le približno $0,15 \%$ zaposlenih. Leta 1995 je bilo vključenih 792 zaposlenih (tabela 1). Polovica vseh specializantov (393) je bila zaposlena v zdravstvu, $115 \mathrm{v}$ izobraževanju, znanosti, kulturi in informacijah in nadaljnjih $58 \mathrm{v}$ državni upravi. $Z$ drugimi besedami, $71 \%$ vseh specializantov je bilo iz javnih storitev. Glede na ravni specializacije so imele prednost specializacije po visokošolski diplomi, programe specializacij po končanih srednješolskih programih in po višješolski diplomi je obiskovalo od skupaj 792 le 113 udeležencev. Ocenjujemo, da so tako majhne potrebe po specializacijah povezane $z$ organizacijo sistema usmerjenega izobraževanja, ki je omogočal ozko poklicno izobraževanje na sekundarni ravni. Prav tako je možno, da delodajalci programe specializacij nadomeščajo z daljšimi poklicnimi izkušnjami, ali pa skušajo specialna znanja in spretnosti zagotoviti s povečevanjem izobrazbenih zahtev.

\subsection{Programi usposabljanja in prekvalifikacij}

Strukturne spremembe v slovenskem gospodarstvu na prehodu v tržno gospodarstvo so nedvomno sprožile val potreb po prekvalifi- kacijah zaposlenih, vendar podatki ne potrjujejo, da bi to občutneje vplivalo na obseg udeležbe zaposlenih $\mathrm{v}$ teh programih (graf 1 in 2). Tudi leta 1995 je verificirane in neverificirane programe prekvalifikacij skupaj obiskovalo le približno $0,5 \%$ vseh zaposlenih. $V$ nobeni od dejavnosti delež udeležencev ni dosegel enega odstotka zaposlenih (tabela 1). Tudi $v$ industriji in rudarstvu, kjer so procesi prestrukturiranja najbolj intenzivni, je bilo vključenih le približno $0,8 \%$ zaposlenih. Seveda je lahko del prekvalifikacij zajet v drugih vrstah usposabljanja in izpopolnjevanja. Nizkokvalificirana delovna sila se pogosto usposablja za drugo delo s krajšim uvajanjem v delo, ki ga tu ne prikazujemo. Vendar je velika verjetnost, da ima v delovnih organizacijah, kjer potekajo procesi prestrukturiranja, prednost odpuščanje delavcev pred vlaganjem $\mathrm{v}$ prilagajanje njihovih kvalifikacij spremenjenim zahtevam proizvodnje. Delodajalci poskušajo na ta način prenesti stroške $\mathrm{v}$ breme javnih sredstev in samih delavcev. $K$ takšni domnevi nas vodi dejstvo, da prestrukturiranje podjetij in firm skoraj praviloma spremlja kolektivno odpuščanje.

Kar zadeva udeleženost zaposlenih v programih USO, pa lahko ugotovimo, da se je ta leta $1995 \mathrm{v}$ primerjavi z letom 1989 celo nekoliko zmanjšala (graf 1). Največji deleži zaposlenih, ki so se leta 1995 usposabljali v programih USO, so bili značilni za stanovanjsko in komunalno dejavnost $(2,5 \%)$, gradbeništvo $(1,13 \%)$, industrijo in rudarstvo (dober odstotek); udeležilo se jih je tudi 1,2\% zaposlenih v kmetijstvu in ribištvu in $0,94 \% \mathrm{za}$ poslenih v obrtnih storitvah. Po drugi strani pa podatki kažejo, da tradicionalne industrijske in storitvene dejavnosti izkazujejo relativno visok odstotek udeležencev izobraževanja in usposabljanja, ki so ga delodajalci dolžni zagotoviti skladno $\mathrm{z}$ zakonskimi predpisi. Iz tabele $1 \mathrm{v}$ prilogi je razvidno, da se je leta 1995 izobraževalo po teh programih med 10 in $20 \%$ zaposlenih iz navedenih dejavnosti. Prevladovalo je usposabljanje iz varstva pri delu. Slabše izobraženemu delu zaposlenih je torej namenjeno predvsem usposabljanje, ki je sankcionirano od zunaj in zadeva njihovo trenutno delo, izobraževanje in usposabljanje, ki bi izboljšalo njihove priložnosti na trgu dela, pa jim je mnogo težje dosegljivo. 


\begin{tabular}{|c|c|c|c|c|c|c|c|c|c|c|c|}
\hline \multicolumn{12}{|c|}{ 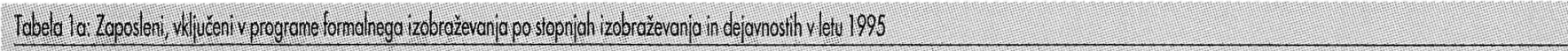 } \\
\hline \multirow{2}{*}{ Dejannosi } & \multirow{2}{*}{$\begin{array}{l}\text { Povpréé ścerio } \\
\text { zopost. } 1995\end{array}$} & \multicolumn{9}{|c|}{ Stopie izobrozbe } & \multirow[b]{2}{*}{ Skupaj } \\
\hline & & osnovno sola & 1. II. in. & N. & y. & $V \| 1$. & W/2 & W1. & Vil/2. & VIII. & \\
\hline Industrigoin rudastvo & 243268 & 96 & 131 & 441 & 765 & 976 & 66 & 34 & 284 & 65 & 3102 \\
\hline Kmelistro in ibibistyo & 8830 & 2 & 0 & 33 & 95 & 36 & 4 & 30 & 33 & 1 & 234 \\
\hline Gozearsto & 2297 & 0 & 0 & 0 & 3 & 19 & 0 & 1 & 3 & 0 & 26 \\
\hline Vodho gespodarstvo & 1070 & 0 & 0 & 0 & 0 & 0 & 1 & 0 & 0 & 0 & 1 \\
\hline Grodbenisivo & 29847 & 0 & 77 & 59 & 55 & 35 & 6 & 21 & 8 & 1 & 262 \\
\hline Promet ingueze & 29918 & 2 & 6 & 75 & 173 & 224 & 6 & 83 & 20 & 0 & 589 \\
\hline Iggoving & 55892 & 6 & 29 & 270 & 650 & 145 & 11 & 53 & 14 & 6 & 1184 \\
\hline Gosinstivin turizem & 15155 & 0 & 0 & 12 & 12 & 13 & 2 & 4 & 6 & 0 & 49 \\
\hline Obri in osebre storike & 14860 & 1. & 22 & 29 & 12 & 9 & 2 & 3 & 0 & 0 & 78 \\
\hline Stanovar Ska in Konuna ho dejounost & 10802 & 0 & 1 & 0 & 0 & 3 & 0 & 0 & 0 & 0 & 4 \\
\hline Finatiche, thincicne in postome storive & 36450 & 0 & 47 & 14 & $\pi$ & 402 & 4] & 251 & 133 & 21 & 988 \\
\hline Zzobraževarie, zarnost, kutura in intormacieje & 51335 & 4 & 18 & 3 & 80 & 145 & 48 & 700 & 413 & 184 & 1595 \\
\hline Zdrovstive in socicho verstvo & 54481 & 20) & 248 & 45 & 128 & 43 & 60 & 260 & 486 & 25 & 1685 \\
\hline Diżung uprava & 38994 & 0 & 6 & 55 & 315 & 497 & 280 & 433 & 216 & 60 & 1862 \\
\hline Skevoi & 594394 & 131 & 585 & 1036 & 2365 & 2917 & 461 & 2183 & 1616 & 363 & 11657 \\
\hline
\end{tabular}

vodsiokiti

Dejovinosi

\begin{tabular}{|c|c|c|c|c|c|c|c|c|c|c|}
\hline & osnovina sola & 1, th inll: & V. & V. & Wh. & 112. & VI/1. & $V \| / 2$ & VII. & Skepdi \\
\hline Industivi a in rudars vo & 0,04 & 0,05 & 0,18 & 0,31 & 0,40 & 0,03 & 0,14 & 0,12 & 0,03 & 1,28 \\
\hline Knethitivo in ribisto & 0,02 & 0,00 & 0,37 & 1,08 & 0,4 & 0,05 & 0,34 & 0,37 & 0,01 & 2.65 \\
\hline Gozderstivo & 0,00 & 0,00 & 0.00 & 0,13 & 0,83 & 0,00 & 0,04 & 0,13 & 0,00 & 1,13 \\
\hline Vodho gospodarstro & 0,00 & 0,00 & 0,00 & 0,00 & 0,00 & 0,09 & 0,00 & 0,00 & 0,00 & 0,09 \\
\hline Grodberisto & 0,00 & 0,26 & 0,20 & 0,18 & 0,12 & 0.02 & 0,07 & 0,03 & 0,00 & 0,88 \\
\hline Pronel in zueze & 0,01 & 0,02 & 0,25 & 0,58 & 0,75 & 0,02 & 0,28 & 0,07 & 0,00 & 1,97 \\
\hline Trgovina & 0,01 & 0.05 & 0,48 & 1,6 & 0,26 & 0,02 & 0,09 & 0,03 & 0,01 & 2,12 \\
\hline Gostinsto in turizen & 0,00 & 0,00 & 0,08 & 0,08 & 0,09 & 0,01 & 0,03 & 0,04 & 0,00 & 0,32 \\
\hline Obrin osebnestoritie & 0,01 & 0,15 & 0,20 & 0,08 & 0,06 & 0,01 & 0,02 & 0,00 & 0,00 & 0,52 \\
\hline Stenovanjkgo in komunaho dejavnost & 0,00 & 0,01 & 0,00 & 0,00 & 0,03 & 0,00 & 0,00 & 0,00 & 0,00 & 0,04 \\
\hline Financher, thrickne in pos love storive & 0,00 & 0,13 & 0,04 & 0,21 & 1,10 & 0,11 & 0,69 & 0,36 & 0,06 & 27 \\
\hline Izobrazevarie, znenost, kuture in intornecie & 0,01 & 0,04 & 0,01 & 0,16 & 0,28 & 0,09 & 1,36 & 0,80 & 0,36 & 3,11 \\
\hline Zerassviv in socidho varstvo & 0,04 & 0,46 & 0,08 & 0,28 & 0,76 & 0,11 & 0,48 & 0,89 & 0,05 & 3,09 \\
\hline Dizama upreva & 0,00 & 0,02 & 0,14 & 0,81 & 1,27 & 0,72 & 1,11 & 0,55 & 0,15 & 4,78 \\
\hline Skupd & 0,02 & 0,10 & 0,17 & 0.40 & 0,49 & 0,08 & 0,37 & 0,27 & 0,06 & 1,96 \\
\hline
\end{tabular}

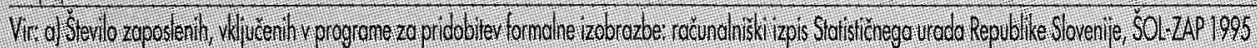

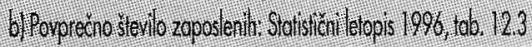

\subsection{Obiskovanje krajših obliik strokovnega izobraževanja, usposabljanja in izpopolnjevanja}

Kot je bilo že omenjeno, k visokemu deležu zaposlenih, ki obiskujejo različne aktivnosti izobraževanja, prispeva levji delež krajše strokovno izobraževanje in izpopolnjevanje, ki je organizirano v obliki seminarjev, tečajev, predavanj, posvetov in strokovnih konferenc ${ }^{3}$. Seveda tudi to izobraževanje ni enakomerno razporejeno med zaposlene. Že samo dejstvo, da gre za strokovno usposabljanje in izpopol- njevanje, nakazuje, da se od udeležencev praviloma pričakuje neka predhodno dosežena raven poklicnega ali strokovnega znanja in spretnosti. S tem je skladna tudi ugotovitev, da se ga $v$ znatno večjem obsegu udeležujejo zaposleni v dejavnostih, ki izkazujejo velik delež zaposlenih z boljšimi izobrazbenimi dosežki. Podatki v tabeli $1 \mathrm{v}$ prilogi kažejo, da se ga je leta 1995 udeležilo kar $122 \%$ zaposlenih v izobraževanju, znanosti, kulturi in informacijah, $65 \%$ zaposlenih v državni upravi, $64 \%$ zaposlenih v zdravstvu in socialnem varstvu. Kar zadeva tržno usmerjene dejavno- 


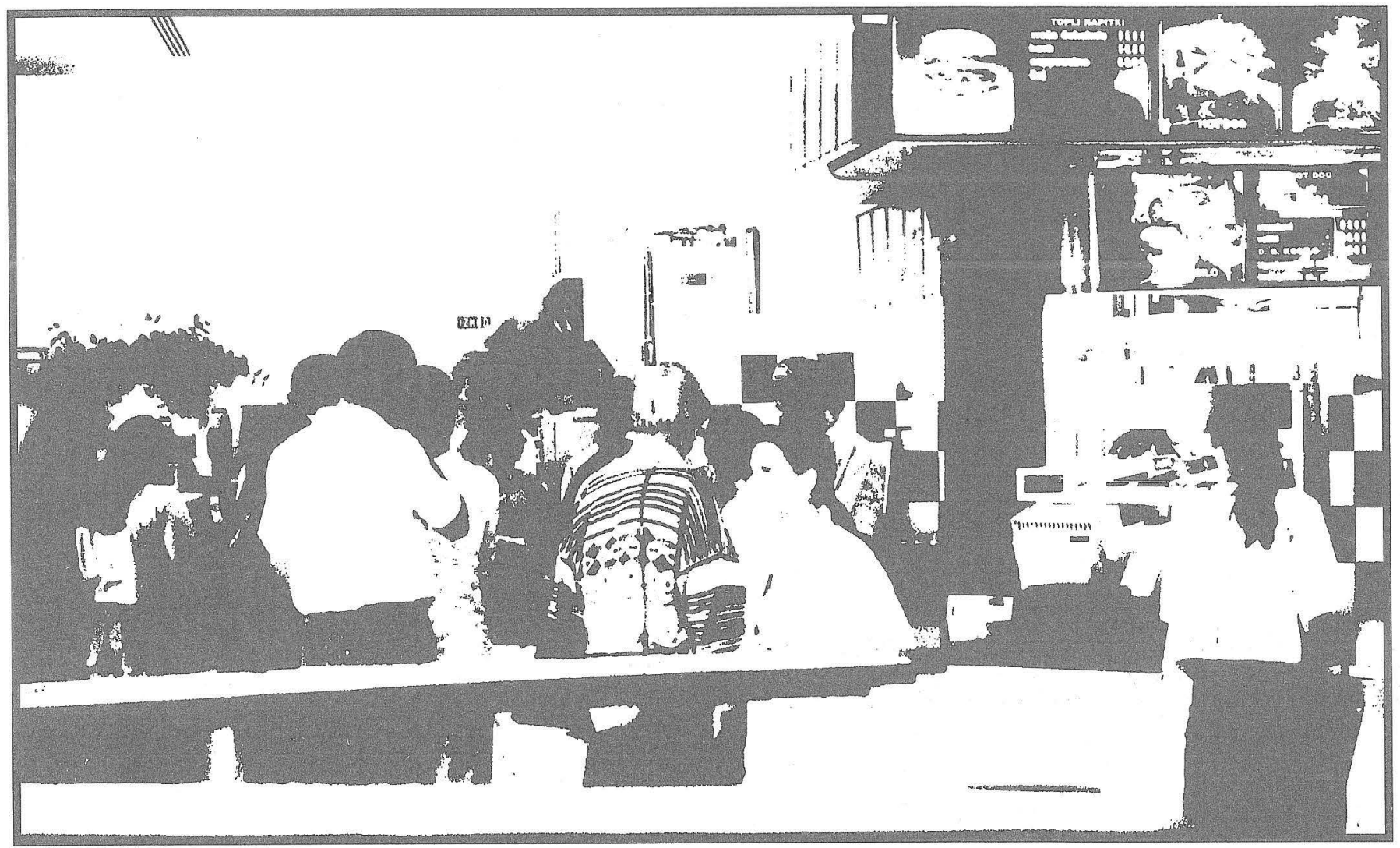

sti je bil primerljiv delež udeležencev $\mathrm{v}$ finančnih, tehničnih in poslovnih storitvah $(62,8 \%)$, deleži udeležencev iz drugih dejavnosti pa so bili bistveno manjši, čeprav še vedno dokaj visoki - gibali so se med $30 \%$ in $35 \%$. Najmanjši delež udeležencev je bil v obrti in osebnih storitvah $(1,5 \%)$, precej večji, vendar še vedno mnogo nižji od povprečnega pa tudi v gradbeništvu $(15,3 \%$ zaposlenih) ter v gozdarstvu (16,6\% zaposlenih). Ta-

\section{Višje izobraženi imajo več možnosti za nadaljnje izobraževanje.}

Obiskovala jih je skoraj četrtina vseh udeležencev. Naslednje dokaj močno zastopano področje je bilo področje družboslovja in behaviorističnih ved z 19,6\% vseh udeležencev; skoraj vsi so se izobraževali in izpopolnjevali $\mathrm{v}$ psihologiji, pedagogiki in andragogiki. Tretje obsežnejše področje pa je bilo področje računalništva in informatike $\mathrm{z} 12,25 \%$ udeležencev. Med najbolj zastopana ožja vsebinska področja pa na prvem mestu lahko uvrstimo psihologijo, pedagogiko in andragogiko $\mathrm{z}$ $19,69 \%$ vseh udeležencev, sledi računalništvo in informatika z $12,25 \%$, na tretjem mestu je varstvo pri delu in požarna varnost $(8,97 \%$ vseh udeležencev), področje standardizacije in kakovosti se je s 7,14\% udeležencev uvrstilo na četrto mesto, računovodstvo in finance s $6,94 \%$ pa na peto mesto. Omeniti velja, da je bilo $\mathrm{v}$ poklicnih, obrtnih in industrijskih programih usposabljanja in izpopolnjevanja le približno $2,9 \%$ vseh udeležencev. Tudi delež udeležencev jezikovnega izobraževanja ni dosegel $5 \%$.

Primerjava z leti 1990 in 1992 kaže, da se je v letu 1995 najbolj povečal delež udeležencev v programih financ in računovodstva, računalništva in informatike, standardizacije in kakovosti ter varstva pri delu in požarne varnosti (glej Mohorčič Špolar, Ivančič 1996: 298, 
tab. 10). To so področja, ki so bodisi podvržena naglemu razvoju ali pa doživljajo intenzivne spremembe zaradi sistemskih sprememb in procesov včlenjevanja $\mathrm{v}$ mednarodne gospodarske tokove in mednarodne povezave.

\section{SKLEP}

Prikazani podatki vodijo k splošnemu sklepu, da postopno oživlja izobraževanje in usposabljanje zaposlenih, ki ga je prekinil proces prestrukturiranja v prvi polovici 90-ih let, obenem pa tudi, da je dostop do organiziranih izobraževalnih dejavnosti dokaj selektiven. Gospodarska dejavnost, očitno pa tudi položaj pri delu in velikost organizacije, čeprav tega ni mogoče sklepati iz navedenih podatkov, so vse bolj pomembni dejavniki izobraževalnih možnosti zaposlenih. Ugotovitev, da se v izobraževalne aktivnosti, najsi gre za pridobitev formalne izobrazbe ali pa za strokovno izpopolnjevanje, $\mathrm{v}$ znatno večjem deležu vključujejo zaposleni v javnih storitvah, je v skladu s tem, da pogosteje nadaljujejo izobraževanje ljudje z boljšimi izobrazbenimi dosežki, kakor tudi, da imajo boljše možnosti izobraževanja zaposleni $\mathrm{v}$ dejavnostih, ki se financirajo iz javnih sredstev, in $\mathrm{v}$ dejavnostih, ki si lahko zagotovijo monopolni položaj na trgu.

Pomembna je ugotovitev, da se povečuje povpraševanje po krajših izobraževalnih aktivnostih, medtem ko ostaja udeležba v daljših programih na dokaj nizki ravni. Sklepamo lahko, da so aktualne tiste izobraževalne aktivnosti, ki se odzivajo na aktualne potrebe delodajalcev. To med drugim tudi opozarja, da klasični programi izobraževanja za pridobitev formalne izobrazbe, ki jih srečujemo na izobraževalnem trgu, najbrž niso ustrezni za izboljševanje izobrazbene ravni delovne sile. Pridobivanje formalne izobrazbe in kvalifikacij bi moralo biti zasnovano tako, da bi bilo čimbolj povezano s poklicnim delom udeležencev, tako bi le-ti lahko preverjali vrednost pridobljenega znanja in spretnosti takoj v svojem delovnem okolju.

Prav tako je očitno, do so poleg programov, ki jih narekujejo zakonski predpisi in sistemske spremembe, iskani programi, ki posredujejo splošnejša znanja in spretnosti, ki se ne omejujejo na eno samo dejavnost ali poklic, marveč bi zanje lahko rekli, da so transpoklicna.

Seveda ne gre pozabiti tudi na vlogo ponudbe na trgu izobraževanja pri takšni porazdelitvi povpraševanja. Da je ta dokaj enostranska, nakazujejo tudi podatki o ponudbi izobraževalnih programov (Izobraževanje odraslih v Sloveniji. Programi/Izvajalci). Tako je v programski ponudbi za leto Boljše možnosti
izobraževanja imajo
zaposleni v javnem
sektorju. $1997 / 98$ od skupaj 2942 programov kar 1262 ali $43 \%$ programov jezikovnega in računalniškega izobraževanja. Hkrati pa izvajalci ponujajo $2 \%$ verificiranih in $1 \%$ neverificiranih programov specializacij na srednji ravni, $4 \%$ verificiranih in $1 \%$ neverificiranih programov USO, medtem ko je programov usposabljanja za delo v drugih strokah $4 \%$.

\section{VIRI}

Davis, N. (1996): Who participates in education and training? - an overview at European level. Vocational Training, European Journal, No. 8/9 May - December 1996/II/III, CEDEFOP, European Centre for the Development of Vocational Training, str. 32-36.

Ivančič, A. (1996): Vseživljenjsko izobraževanje in socialna neenakost. V: Svetlik I. (ured.), Kakovost življenja v Sloveniji, FDV, Ljubljana, str. 45-80.

Izobraževanje odraslih v Sloveniji 1997/98: Izvajalci/Programi. Andragoški center Slovenije, Ljubljana, 1997.

Mohorčič Špolar, V. A., A. Ivančič (1996): Potrebe po izobraževanju odraslih. Študije in raziskave 5, ACS, Ljubljana.

Smonkar, J. (1994): Izobrazbena struktura in vključenost v izobraževanje. V: Zaposlovanje, približevanje Evropi, FDV, Ljubljana, str. 105-121.

\footnotetext{
${ }^{1}$ Naj opozorim, da so podatki, zbrani s to raziskavo, deležni številnih kritik praktikov na področju izobraževanja $v$ gospodarstvu. Te kritike predvsem zadevajo neprofesionalen odnos pri posredovanju podatkov v podjetjib in firmah. Ne glede na to so to edini uradni podatki, ki podrobneje razčlenjujejo udeležbo zaposlenib v izobraževanju, in so na razpolago vsako leto, kar omogoča tekoče spremljanje gibanj $v$ daljšem časovnem obdobju.

2 Podrobnejsi podatki bi verjetno pokazali, da so programi nižjega poklicnega izobraževanja omejeni na socialno varstvo.

${ }^{3}$ Opozoriti je treba, da je dejansko število udeležencev teh oblik bistveno maniše od prikazanega, ker so podatki zbrani tako, da vsaka udeležba pomeni enega zaposlenega. To pojasnjuje tudi podatek $v$ nadaljevanju, da se je tega izobraževanja udeležilo $122 \%$ zaposlenib v izobraževanju, znanosti, kulturi in informacijab. Dejansko so nekateri delavci/skupine delavcev večkratni udeleženci, medtem ko so drugi iz njib izključeni.
} 